\title{
Total Petroleum Hydrocarbons By Gas Chromatography in Colombian Waters and Soils
}

\author{
Cortes, J.E., A. Suspes, S. Roa, C. González and H.E. Castro \\ Department of Chromatography, \\ Antek S. A-Environmental and Petroleum Geochemistry \\ Laboratory-Environmental Division, Calle 25B No 85B-54, Bogotá, Colombia
}

Received 2012-01-13; Revised 2012-06-04; Accepted 2012-06-20

\begin{abstract}
Total Petroleum Hydrocarbons (TPHs) were required by the Colombian Environmental Authorities. However, the great diversity of hydrocarbon sources, in addition to the variety of available techniques and analytical methods had created confusion among the users of the data in regards to the appropriate methodologies. This study presents the results obtained in the method validation for the determination of TPHs in waters and soils/sediments using the HRGC/FID technique and its application in the Colombian Exploration and Production (E\&P) industry. HRGC coupled to FID Detector (HRGC/FID) was used to determine individual alkane hydrocarbon in the Gasoline Range (GRO) and Diesel Range (DRO). The limit of detection was established in $0.020 \mu \mathrm{g} \mathrm{mL}^{-1}$ for waters and $2.30 \mu \mathrm{g} \mathrm{g}^{-1}$ for soils and sediments. The recovery percentage of water samples were 101 and $98 \%$, while for soils was 99 and $97 \%$ for both, low and high levels of $n$-alkane hydrocarbons, respectively. This method is an economical, fast and accurate way to determinate TPHs and individual alkane hydrocarbons in water and soil samples. The method provides the robustness, limit of detection and percentage of recovery enough to comply with Colombian environmental regulations.
\end{abstract}

Keywords: Total Petroleum Hydrocarbons (TPHs), Gasoline Range Organic (GRO), Limit of Detection (LOD), Flame Ionization Detector (HRGC/FID), Hexane Extractable Material (HEM), Unresolved Complex Mixture (UCM)

\section{INTRODUCTION}

The term TPHs has been used to describe a wide variety of chemical compounds derived from crude oil and its by-products. The TPHs are a complex mixture of compounds with different polarities extracted from crude oil using organic solvents (Gustafson, 2007). The physicochemical characteristic of the individual alkane hydrocarbons present in water and soil/sediment samples will depend on the source of contamination (gasoline, diesel, kerosene, fuel oil, mineral oil or asphaltic material) spilled or widespread in the environmental matrices.

For the last decade, TPHs in water, soil and air samples have been required by the Colombian Environmental authorities (MS, 1984; MAVDT, 2010a; $2010 \mathrm{~b} ; 2010 \mathrm{c}$ ). The numerous sources of hydrocarbons combined with the variety of available techniques and analytical methods have created confusion among the end users of the data in regards to the appropriate methodologies. Users, government laboratories and private laboratories disagree on the scope, range of application and quality of information obtained from using different methods.

There are several methods for determining TPHs in environmental samples, however due to their specificity; most are only applied to designated petroleum fractions (Saddler and Connen, 2003). The methods, based on the determination of grease and oil ( $\mathrm{G}$ and A) by EPA 413.1 (halogenated solvent extraction and gravimetry) and 413.2 (halogenated solvent extraction and infrared) and EPA 418.1 (EPA, 1993), which permits the extraction of the TPHs with Freon or $\mathrm{CCl}_{4}$ and IR analysis in the C-H stretch $\left(3240 \mathrm{~cm}^{-1}\right)$, are particularly sensitive to mineral oils and diesel, but do not yield the desired results when a sample contains products with high aromaticity such as gasoline and reforms. $\mathrm{G}$ and $\mathrm{A}$ and TPH by IR do not 
consistently indicate contamination in petroleum. For example, a water or soil sample with a high concentration of humic or fulvic acids (non-petrogenic organic compounds) would give a false positive due to the strong absorbance of those compounds in the IR range (AWWA, 1998).

Recently, the U.S. EPA has removed methods that use Freon-113 as an extraction solvent and, as an alternative, recommended the use of the method EPA1664: n-Hexane Extractable Material (HEM; Oil and Grease) and silica gel treated with n-hexane extractable material (SGT-HEM; Nonpolar Material) by extraction and gravimetry (EPA, 1999)

In the late 90's, the U.S. EPA published the SW-846 methods for solid waste, which included the EPA-8015 method for TPH determination using the GC technique. However, this method was originally designed for solvent evaluation rather than petroleum hydrocarbons. The EPA SW-846, III revision included the new 8015D method called "Non-halogenated volatile organic compounds using GC/FID", which included a guide to determine hydrocarbons in the Gasoline (GRO) and Diesel (DRO) range.

This study presents the results obtained in the analytical validation carried out in the Antek S.A. Environmental and Geochemical Laboratory- for the determination of petroleum hydrocarbons in waters and soils/sediments using the HRGC/FID technique and a Colombian gasoline/diesel mixture as a reference standard. Once validated, the method was used to determine TPHs and individual n-alkanes in water and soil matrices (freshwater, petroleum wastewater, groundwater, formation waters and soil/sediments from petroleum treatment pits) in the Colombian Exploration and Production (E\&P) industry.

\section{MATERIALS AND METHODS}

\subsection{Monitoring, Preservation and Sample Treatment}

\subsection{Solid and Water Samples}

The holding time for solid and water samples was 14 days from collection to GC analysis. Samples were refrigerated at $<4^{\circ} \mathrm{C}$ until its organic extraction. Aqueous samples were collected in $40 \mathrm{~mL}$ amber vials with a whole cap and a Teflon septum. Samples were preserved at $\mathrm{pH}<2.0$ with sodium bisulfite, $\mathrm{HCl}$ or $\mathrm{H}_{2} \mathrm{SO}_{4} .10 \mathrm{~mL}$ of the sample were removed and discarded through the septum with glass syringe. $3 \mathrm{~mL}$ of n-pentane were then injected through the septum with a $5 \mathrm{~mL}$ syringe. The sample was extracted for $2 \mathrm{~m}$ in a vortex apparatus. The vial was then opened and $1.5 \mathrm{~mL}$ of the organic extract were placed into the vial and sent for the GC analysis.
The solid samples were collected in $20 \mathrm{~mL}$ vials with a solid cap and a Teflon septum. $10 \mathrm{~g}$ of soil or sediment were extracted with $20 \mathrm{~mL}$ of n-pentane. Analytical field and laboratory blanks and duplicated and spiked samples were treated the same as the water and soil/sediment samples. After adding the n-pentane, the samples were shaken for $15 \mathrm{~m}$ by the ultrasonic apparatus and allowed to settle for $30-60 \mathrm{~m}$ at room temperature. Two additional extractions, each with 20 $\mathrm{mL}$ of n-pentane, were performed in the same manner. $1.0 \mathrm{~mL}$ of the organic extract was then transferred into a vial and analyzed by GC/FID.

\subsection{Chromatography Conditions}

GC/FID analysis of the TPHs and PHs was made on a Hewlett Packard 5890 Series II-Plus gas chromatograph equipped with an HP 7673 Autosampler and FID detector coupled with a $30 \times 0.32 \mathrm{~mm}$ DB-5 (95 metil-5\%-fenilpolisiloxane) fused silica capillary column. The oven temperature was programmed from $40^{\circ} \mathrm{C}$ (3 min.) to 300 at $15^{\circ} \mathrm{C} / \mathrm{min}$. Samples were injected in splitless mode, with the relay open at $20 \mathrm{sec}$. Injector and detector temperatures were 250 and $320^{\circ} \mathrm{C}$, respectively. Helium was used as the carrier gas at a linear velocity of $38 \mathrm{~cm} \mathrm{sec}^{-1}$ (15 psig). Data handling was done with Agilent Chemstation chromatography software (version 10).

\section{RESULTS}

\subsection{Calibration}

Fresh standards were prepared in n-pentane. To build the calibration curve, a $10000 \mu \mathrm{g} \mathrm{mL}{ }^{-1}$ standard stock was prepared with commercial unleaded gasoline and diesel \#2 (1:1) acquired in a commercial gasoline station in Bogotá, Colombia. Additionally, an analytical standard containing $200 \mu \mathrm{g} \mathrm{mL}^{-1}$ of $\mathrm{n}-\mathrm{C} 10$ to $\mathrm{n}-\mathrm{C} 28$ of alkane hydrocarbons mix was used for identification purposes. Initial calibration curves were prepared with a range of 50-1000 $\mu \mathrm{g} \mathrm{mL}^{-1}$ from the standard stock.

For quantification purposes, the peak area for TPHs was determined using forced line integration with Agilent Chemstation software between n-hexane (n-C6) through n-pentatriacontane (n-C35) or until the last peak eluted in the chromatographic profile. For individual PHs the area of each peak was calculated using the baseline-baseline mode and external response factor quantization. According to TNRCC-1005, the correlation for calibration curves must be $\geq 0.990$ and the relative standard deviation of the response factors for each of calibration levels must be less than $25 \%$ of the overall calibration range (Table 2) (TNRCC, 2001). Figure 1 shows the chromatographic profile of 
the standard mix containing $1000 \mu \mathrm{g} \mathrm{mL} \mathrm{L}^{-1}$ of TPHs prepared from the standard stock of $10000 \mu \mathrm{g} \mathrm{mL} \mathrm{m}^{-1}$ of the gasoline: diesel mix.

\subsection{Validation Results}

The Limit of Detection (LOD) was determined by injecting a standard of $20 \mu \mathrm{g} \mathrm{mL} \mathrm{m}^{-1}$ of alkane hydrocarbons 5 times according to CFR 40 part. 136 U.S. EPA, 2012. The LOD in the aqueous matrix was established in $0.020-30 \mathrm{~mL}$ of water extracted, while for the solid matrix (soil/sediments) was calculated at 2.30 $\mu \mathrm{g} \mathrm{g}^{-1}$ per $10 \mathrm{~g}$ of sample extracted.

The precision was determined using water and soil samples containing three different levels 0.02, 1.0 and 5.0 $\mathrm{mg} \mathrm{L}^{-1}$ for waters and $12000 \mu \mathrm{g} \mathrm{g}^{-1}$ of TPHs, respectively.

\section{DISCUSSION}

Comparison of typical calibration curves for TPHs between different operators showed an average correlation of 0.9996 , which indicated an excellent linearity in the range evaluated and consequently guaranty that any PHs concentration present in aqueous and solid samples could be determinate with reliable precision and accuracy in such range.

Table 1 shows that the standard deviation of the concentrations (precision) was $\pm 3 \mu \mathrm{g} \mathrm{mL}^{-1}$ for water samples and $\pm 2025 \mu \mathrm{g} \mathrm{g}^{-1}$ for soil samples. The relative standard deviation was 6 and $2 \%$ for each matrix, respectively.

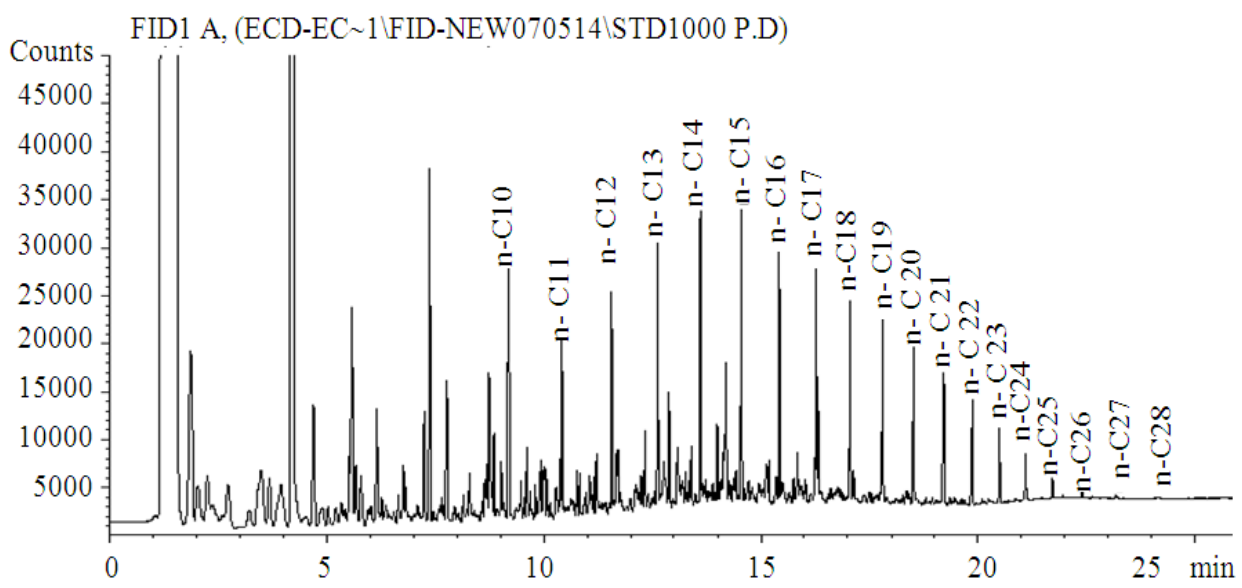

Fig. 1. Chromatographic profile of Colombian gasoline: diesel (1:1) standard of $1000 \mu \mathrm{gL}^{-1}$

FID1 A, (ECD-EC 1\FID-NEW070509\AGU700.D)

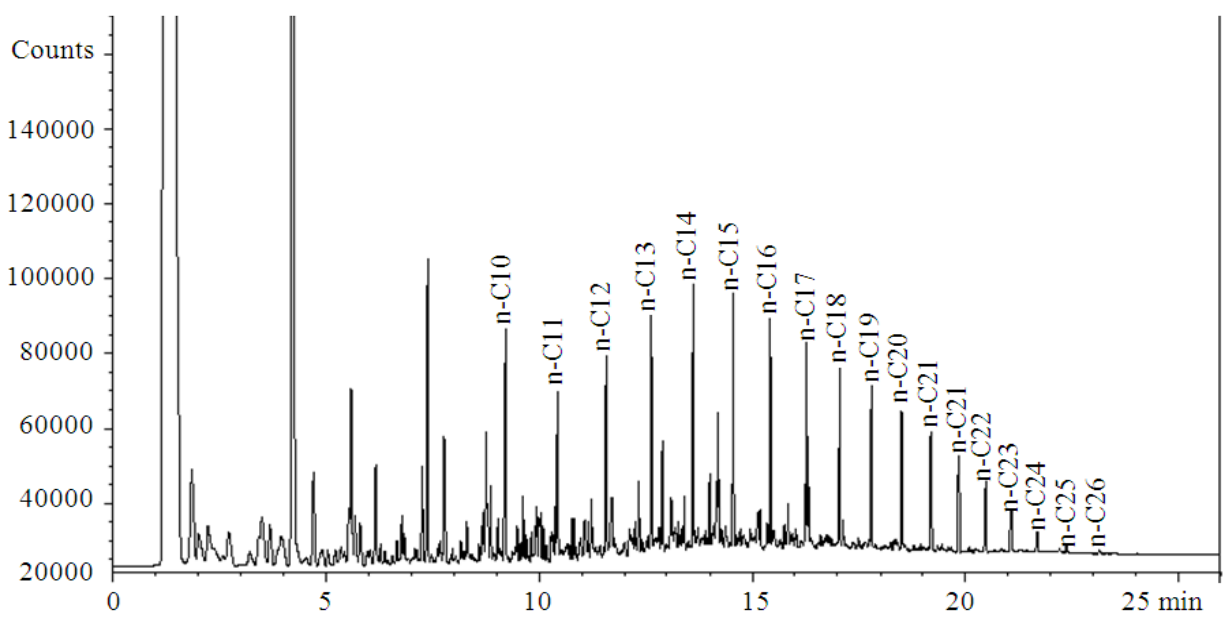

Fig. 2. Chromatographic profile of spiked water sample spiked with $233 \mu \mathrm{g} \mathrm{mL} \mathrm{L}^{-1}$ of PHs 
Cortes, J.E. et al. / American Journal of Environmental Science 8(4) (2012) 396-402

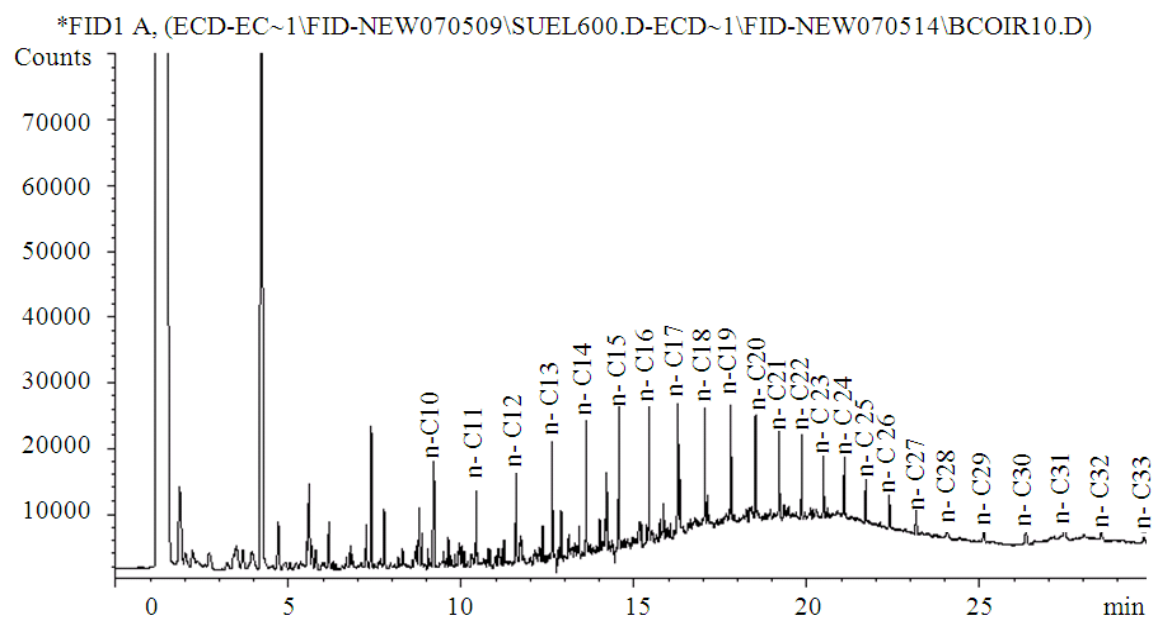

Fig. 3. Chromatographic profile of spiked soil sample spiked with $3000 \mu \mathrm{g} \mathrm{g}^{-1} \mathrm{PHs}$

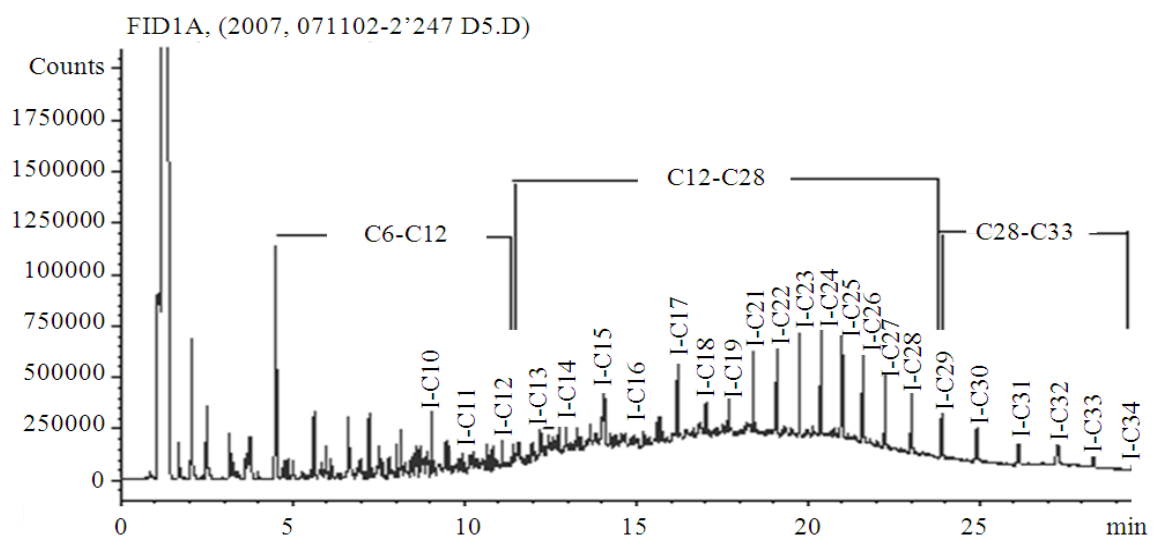

Fig. 4. GC/FID profile of a waste water sample (Antek-24705) from a petroleum treatment mud pit showing the individual n-alkane distribution

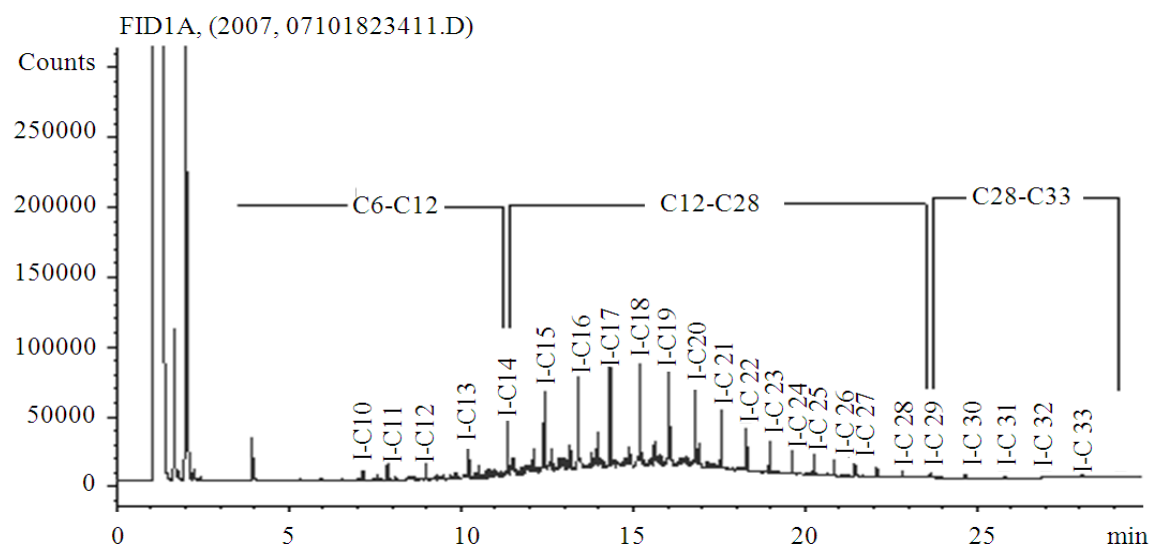

Fig. 5. GC/FID chromatogram of a contaminated soil (Antek-23411) from a treatment petroleum mud pit showing the individual nalkane distribution 
Cortes, J.E. et al. / American Journal of Environmental Science 8(4) (2012) 396-402

Table 1. Precision of the TPHs method for Colombian water and soil samples

\begin{tabular}{|c|c|c|c|c|c|c|}
\hline & \multicolumn{3}{|c|}{ Concentration $(\mu \mathrm{g} / \mathrm{g})$} & \multicolumn{3}{|c|}{ Concentration $(\mu \mathrm{g} / \mathrm{mL})$} \\
\hline & Water & Water & Water & Soil & Soil & Soil \\
\hline SAMPLE & $12139-1$ & $12139-2$ & $12139-3$ & $11178-1$ & $11178-2$ & $11178-3$ \\
\hline DAY 1 & 45.0 & 49 & 44 & 116086 & 118015.0 & 119436.0 \\
\hline DAY 2 & 38.0 & 46 & 46 & 114918 & 114611.0 & 116364.0 \\
\hline DAY 3 & 43.0 & 43 & 44 & 118792 & 119395.0 & 116974.0 \\
\hline Average & 42.0 & 46 & 45 & 116599 & 117340.0 & 117591.0 \\
\hline Standard deviation & 4.0 & 3 & 1 & 1987 & 2462.0 & 1626.0 \\
\hline Aver. Standard deviation & & 3 & & & 2025.0 & \\
\hline CV \% & 9.0 & 7 & 3 & 2 & 2.0 & 1 \\
\hline Average CV\% & 6.0 & & & & 2.0 & \\
\hline
\end{tabular}

Table 2. Response Factors for five calibration levels. Calibration curves were done on three different days by three different technicians

\begin{tabular}{llll}
\hline $\begin{array}{l}\text { Calibration } \\
\text { Level }\end{array}$ & $\begin{array}{l}\text { Response factor } \\
\text { Calibration } \\
\text { curve no 1 }\end{array}$ & $\begin{array}{l}\text { Response factor } \\
\text { calibration } \\
\text { curve no 2 } \\
\text { Day 2 } 2\end{array}$ & $\begin{array}{l}\text { Response factor } \\
\text { calibration } \\
\text { curve no } 3 \\
\text { Day 3 }\end{array}$ \\
\hline 50 & 0.000256 & 0.00027 & 0.000341 \\
100 & 0.000339 & 0.000358 & 0.000351 \\
200 & 0.000336 & 0.000348 & 0.000365 \\
500 & 0.000333 & 0.000348 & 0.000338 \\
1000 & 0.000333 & 0.000336 & 0.000340 \\
Average & 0.000319 & 0.000332 & 0.000347 \\
Standard Dev. & 0.000031 & 0.000031 & 0.000010 \\
Relative Std Dev. & 9.000000 & 9.000000 & 3.000000 \\
\hline
\end{tabular}

Table 3. Accuracy of the method using spiked water samples

\begin{tabular}{|c|c|c|c|c|c|c|}
\hline \multirow[b]{2}{*}{$\begin{array}{l}\text { Water } \\
\text { samples }\end{array}$} & \multicolumn{6}{|c|}{ Petroleum Hydrocarbons (PHs) } \\
\hline & $\begin{array}{l}\text { Experimental } \\
\text { concentration, } \\
(\mu \mathrm{g} / \mathrm{mL})\end{array}$ & $\begin{array}{l}\text { Theoretical } \\
\text { concentration, } \\
(\mu \mathrm{g} / \mathrm{mL})\end{array}$ & Recovery, $(\%)$ & $\begin{array}{l}\text { Average } \\
\text { recovery (\%) }\end{array}$ & $\begin{array}{l}\text { Standard } \\
\text { Deviation }\end{array}$ & $\mathrm{CV} \%$ \\
\hline Low 1a & 53 & 50 & 106 & 102 & 7 & 7 \\
\hline Low $1 b$ & 52 & & 104 & & & \\
\hline Low 1c & 46 & & 92 & & & \\
\hline Low $2 a$ & 55 & & 110 & & & \\
\hline Low $2 b$ & 53 & & 106 & & & \\
\hline Low 2c & 46 & & 92 & & & \\
\hline High 1a & 237 & 233 & 102 & 98 & 3 & 3 \\
\hline High $1 b$ & 220 & & 94 & & & \\
\hline High $1 \mathrm{c}$ & 225 & & 97 & & & \\
\hline High $2 a$ & 236 & & 101 & & & \\
\hline High $2 b$ & 222 & & 95 & & & \\
\hline High $2 c$ & 224 & & 96 & & & \\
\hline
\end{tabular}

Table 4. Determination of \% recovery in spiked soil samples

\begin{tabular}{|c|c|c|c|c|c|c|}
\hline \multirow[b]{2}{*}{$\begin{array}{l}\text { Soil } \\
\text { samples }\end{array}$} & \multicolumn{3}{|c|}{ Petrogenic Hydrocarbons } & \multirow[b]{2}{*}{$\begin{array}{l}\text { Average } \\
\text { recovery (\%) }\end{array}$} & \multirow[b]{2}{*}{$\begin{array}{l}\text { Standard } \\
\text { deviation }\end{array}$} & \multirow[b]{2}{*}{$\mathrm{CV} \%$} \\
\hline & $\begin{array}{l}\text { Experimental } \\
\text { concentration } \\
(\mu \mathrm{g} / \mathrm{g})\end{array}$ & $\begin{array}{l}\text { Theoretical } \\
\text { concentration } \\
(\mu \mathrm{g} / \mathrm{g})\end{array}$ & $\begin{array}{l}\text { Recovery } \\
(\%)\end{array}$ & & & \\
\hline Low 1a & 979 & 989 & 99 & 99 & 0.1 & 0.1 \\
\hline Low $1 \mathrm{~b}$ & 982 & 993 & 99 & & & \\
\hline Low 1c & 984 & 995 & 99 & & & \\
\hline High 1a & 2897 & 3000 & 97 & 97 & 0.1 & 0.1 \\
\hline High $1 b$ & 2898 & 3000 & 97 & & & \\
\hline High 1c & 2895 & 3000 & 97 & & & \\
\hline
\end{tabular}


Table 5. Comparison of EPA 418.1 by IR and GC/FID method in the quantitative determination of PHs in samples from Colombian petroleum industry

\begin{tabular}{lcc}
\hline & $\begin{array}{l}\text { PHs Concentration } \\
\text { Extraction and IR }\end{array}$ & $\begin{array}{l}\text { Extraction and } \\
\text { GC/FID TNRCC, } \\
\text { Texas 1005 }\end{array}$ \\
Samples & EPA 418.1 & 234042 \\
\hline $\begin{array}{l}\text { Antek } 22205- \\
\text { water, }(\mu \mathrm{g} / \mathrm{mL})\end{array}$ & 205764 & 5198 \\
$\begin{array}{l}\text { Antek } 23410- \\
\text { water, }(\mu \mathrm{g} / \mathrm{mL})\end{array}$ & 5331 & 22036 \\
$\begin{array}{l}\text { Antek } 23411- \\
\text { water, }(\mu \mathrm{g} / \mathrm{mL})\end{array}$ & 22105 & 570 \\
$\begin{array}{l}\text { Antek } 18371- \\
\text { Soil, }(\mu \mathrm{g} / \mathrm{g})\end{array}$ & 510 & 49262 \\
$\begin{array}{l}\text { Antek } 22148- \\
\text { Soil, }(\mu \mathrm{g} / \mathrm{g})\end{array}$ & 47369 & \\
\hline
\end{tabular}

Table 2 shows the response factors for each concentration level in three calibration curves built in 3 different days. For a specific concentration, the response factor could be taken as an expression of the calibration sensitivity. In a linear calibration, the response factors were similar and followed the slope of the curve. The variation coefficients for the average response factors over the five calibration levels on three different days were 9, 9 and $3 \%$, respectively, which comply with the TNRCC-1005 requirement for the \% C.V. which must be less than $25 \%$ overall calibration range.

The accuracy was calculated measuring spiked water and soil samples in two different ranges. Water samples were analyzed six times. Figure 2 shows the chromatographic profile for a sample of water spiked with $233 \mu \mathrm{g} \mathrm{mL}^{-1}$, while the results of the accuracy study are shown in Table 3. The recoveries of TPHs in water samples spiked with 50 and $233 \mu \mathrm{g} \mathrm{mL}^{-1}$ were 102 and $98 \%$, with relative standard deviations of 7 and $3 \%$, respectively.

Soil samples were analyzed in triplicate. Figure 3 shows the chromatographic profile of a soil sample spiked with $3000 \mu \mathrm{g} \mathrm{g}^{-1}$ of PHs. The results in Table 4 show that the recoveries for soil spiked with 990 and $3000 \mu \mathrm{g} \mathrm{mL}^{-1}$ yielded 99 and $97 \%$ with relative standard deviations of 0.1 and $0.1 \%$, respectively.

\subsection{Petroleum Hydrocarbons in Colombian Water and Soil Samples}

Table 5 compares the results obtained by EPA 418.1 method (solvent extraction and infrared) with the method validated in this study, based on TNRCC-1005, in water and soil samples. Although the results are similar and its differences fall within the standard deviation (precision) for each method, the EPA-418 does not determine the source and physicochemical characteristics of the contamination. The chromatographic profile shown in Fig. 4 shows that the sample Antek-24705 has a unimodal hydrocarbon distribution between $n-C_{6}$ to $n$ $\mathrm{C}_{33}$ with a hump between $\mathrm{n}-\mathrm{C}_{12}$ to $\mathrm{n}-\mathrm{C}_{29}$ known as an "Unresolved Complex Mixture" (UCM). The abundance of low molecular weight hydrocarbons $(<$ n-C23) suggests that the contamination in this water sample is recent and has the characteristics of light crude oil, or that the source of the hydrocarbon mixture is a combination of crude oil and a light by-product such as gasoline, diesel, or jet fuel. The presence of a UCM indicates that the crude oil present in the sample had originally a biodegradation in progress or that such process began in the treatment pit. According to TNRCC-1005, the sample shows the presence of Gasoline Range Organic (GRO), which is between n-C6 to n-C12 and Diesel Range Organic (DRO) n-C12-n-C28.

Antek 23411 soil samples (Fig. 5) shows a unique fingerprint associated with a contamination of crude oil. However the absence of low molecular weight hydrocarbons $(<\mathrm{n}-\mathrm{C} 23)$ could indicate that this fraction has been lost by a weathering process (evaporation) in the pit. Additionally the low UCM in the sample suggests that there was no biodegradation process in progress in the original crude oil sample. In this particular case, the unimodal distribution between n$\mathrm{C} 8$ to $\mathrm{n}-\mathrm{C} 33$ with major peaks around $\mathrm{n}-\mathrm{C} 17$ suggest that the crude oil sample was sourced in an algalmicrobial pale environment, which could serve to identify source contamination when there are several sources of such contamination.

\section{CONCLUSION}

This study presents the analytical validation of a method to determine the TPHs and individual petroleum hydrocarbons between n-C6 to n-C35 in Colombian water and soil/sediment samples using HRGC/FID. The method was applied successfully to determine TPHs in the $\mathrm{E}$ and $\mathrm{P}$ petroleum industry.

The Limit of Detection (LOD) in an aqueous matrix was established at 0.020 per $30 \mathrm{~mL}$ of water extracted, while for solid matrices (soil/sediments) it was calculated at $2.30 \mu \mathrm{g} \mathrm{g}^{-1}$ per $10 \mathrm{~g}$ of sample extracted. The precision was determined using soil and water samples containing $12000,0.02,1.0$ and $5.0 \mathrm{mg} \mathrm{L}^{-1}$ of PHs, respectively. The results obtained for the standard deviation of the sampled areas was $\pm 3 \mu \mathrm{g} \mathrm{mL}^{-1}$ for water samples and $\pm 2025 \mu \mathrm{g} \mathrm{g}^{-1}$ for soil samples. The relative 
standard deviation was 6 and $2 \%$ for each matrix, respectively. The method was linear with a range of 50$1000 \mu \mathrm{g} \mathrm{mL}^{-1}$ with a correlation of 0.9996 on average for two operators working at the same operative conditions. The relative standard deviation for the average response factors over five calibration levels of three different days was 9,9 y $3 \%$, respectively. Those values comply with the TNRCC-1005 requirement for $\%$ C.V., which must be less than $25 \%$ of the overall calibration range.

The accuracy was calculated measuring spiked water and soil samples in two different ranges. Water samples were analyzed six times. Figure 2 shows the chromatographic profile for a sample of water spiked with $233 \mu \mathrm{g} \mathrm{mL}^{-1}$, while the results of the accuracy study are shown in Table 3. The recoveries of TPHs in water samples spiked with 50 and $233 \mu \mathrm{g} \mathrm{mL}^{-1}$ were 102 and $98 \%$, with relative standard deviations of 7 and $3 \%$, respectively.

The results obtained by this validated method are comparable with those obtained by the EPA 418.1 method (solvent extraction and IR). Though the results were similar, the presented method is fast, reliable and allows the source and characteristics of the contamination to be determined. This fingerprinting process allows differentiation between hydrocarbons from crude oil and gasoline by-products, diesel or lube oil.

\section{ACKNOWLEDGMENT}

The authors would like to thank Antek S.A., Bogotá, Colombia, for its support in the experimental work done in the Gas chromatography laboratory and for permitting this publication of the validation data. The authors would like to express their gratitude to Geol. E. De Lillard for his assistance during manuscript preparation.

\section{REFERENCES}

AWWA, 1998. American Water Works Association. 1st Edn., American Water Works Association, USA., ISBN-10: 0898679710, pp: 682.

EPA, 1993. Methods for Chemical Analysis and Waste. 3rd Edn., Environmental Monitoring System Laboratory-Cincinnati (EMSL-Ci) Cincinnati, Ohio.

EPA, 1999. Office of Solid Waste.

Gustafson, J.B., 2007. Using TPH in Risk-Based Corrective Action.

MAVDT, 2010a. Decreto 3039 de 2010. Usos de Agua y residuos líquidos.

MAVDT, 2010b. Resolución 1543 de 2010. Términos de referencia para la elaboración del Estudio de Impacto Ambiental para los proyectos de perforación exploratoria de hidrocarburos.

MAVDT, 2010c. Resolución 1544 de 2010. Términos de referencia para la elaboración del Estudio de Impacto Ambiental para los proyectos de perforación exploratoria de hidrocarburos.

MS, 1984. Decreto 1594 de 1984. Usos del Agua y Residuos Liquidos.

Saddler, R. and D. Connell, 2003. Analytical methods for the determination of total petroleum hydrocarbons in soil. Proceeding of the 5th national workshop on the assessment of site contamination, National Environment Protection Council Service Corporation.

TNRCC, 2001. Total Petroleum Hydrocarbons TNRCC Method 1005. 